\title{
HUNGRY TO SELL, HUMBLE TO SERVE: TOWARDS UNDERSTANDING THE USE OF AMBIDEXTERITY IN OPTIMIZING THE SALES AND SERVICE MIX
}

Päivi Karhu, WU Vienna, Austria

Bodo B. Schlegelmilch, WU Vienna, Austria

\begin{abstract}
Service and sales employees represent a substantial segment of the global workforce, and firms' economic success hinges upon their performance. Firms opt to organize sales and service tasks differently; these duties can be merged or separated into distinct units of the organization. Sub-optimal organization of sales and service may lead to low job satisfaction, inadequate job performance and up to $100 \%$ annual employee turnover rates.

This paper suggests that obtaining ambidextrous skills, i.e. the ability to engage in ostensibly contrasting tasks that are interdependent and non-substitutable for the firm, may assist in organizing sales and service in an ideal way. Deliberate allocation of financial and human resources between sales and services drives strategic realization of ambidexterity. This is likely to result in positive performance outcomes and a sustainable firm strategy. Consequently, ambidexterity should be leveraged at all levels of the organization to support an optimal mix of sales and service. To this end, the decision for organizing sales and services calls for top management team's ambidextrous skills.
\end{abstract}

References available upon request. 